\title{
Organogenesis from in vitro-derived Leaf and Internode Explants of Hoya wightii ssp. palniensis - a Vulnerable Species of Western Ghats
}

\author{
Subbaiah Revathi Lakshmi ${ }^{1}$, Jambarapu Herald Franklin Benjamin ${ }^{1}$, Tirupathi Senthil \\ Kumar $^{2}$, Garimella Venkata Suryanarayana Murthy ${ }^{3}$ and Mandali Venkateswara Rao ${ }^{1^{*}}$ \\ ${ }^{1}$ Department of Plant Science; ${ }^{2}$ Department of Industry University Collaboration; Bharathidasan University; \\ Tiruchirappalli 620 024; Tamil Nadu. ${ }^{3}$ Botanical Survey of India; Southern Circle; Coimbatore- 641 003; Tamil \\ Nadu
}

\begin{abstract}
An efficient system was developed for indirect plant regeneration from in vitro-derived leaf and internode explants of Hoya wightii ssp. palniensis. Maximum percentage of the organogenic callus was obtained on MS medium supplemented with NAA (1.0 mg/l) and 2,4-D (2.0 mg/l). The best shoot bud induction was observed on MS medium with $B A(1.0 \mathrm{mg} / \mathrm{l})+I B A(0.5 \mathrm{mg} / \mathrm{l})$. The coconut water $(15 \%)$ was better, resulting in a differentiation of the shoot initials in to well-developed shoots. The elongated shoots (> $3 \mathrm{~cm}$ long) were rooted on a full strength MS basal medium, supplemented with $0.2 \mathrm{mg} /$ of IBA. Finally, the rooted plants were transferred to the soil with $80 \%$ success rate. This protocol was utilized for the in vitro propagation of this endangered plant species.
\end{abstract}

Key words: In vitro explants, organogenesis, Hoya wightii ssp. Palniensis, vulnerable plant, growth regulators

\section{INTRODUCTION}

Hoya wightii ssp. palniensis, commonly known as wax plant due to its waxy nature, belongs to the family Asclepiadaceae. It is a woody trailing herb, endemic to Pambar Shola of Western Ghats of Tamil Nadu, India. Mathew (1992) and Matthew (1996) reported an individual population of $H$. wightii ssp. palniensis in the ravine of Pambar Shola, Tamil Nadu, India. The genus Hoya is of horticultural importance in Europe, Australia and America. H. wightii ssp. palniensis possesses white flowers with red coronas which are borne in an umbel that can last for a week. Seed setting is very rare. Single follicle setting was observed during 2007 at Vattakanal Conservation Trust by the authors. These features limit its population to
Western Ghats of Tamil Nadu, India. Imminent extinction threat of this species necessitates developing the conservation strategies and in vitro tissue culture techniques appear as a promising alternative to ensure its regeneration and conservation. Plant regeneration through organogenesis and somatic embryogenesis has been reported in other species of Hoya such as $H$. kerrii (Tube et al. 2007) and H. carnosa (Maraffa et al. 1981) and micropropagation of this species (Lakshmi et al. 2010).

The present study describes a protocol for the organogenesis of this species from in vitro derived leaf and internode explants since the use of in vitro derived explants will eliminate the need for disinfection. Shoot regeneration from in vitro derived explants have been reported in other plants

\footnotetext{
*Author for correspondence: mvrao_456@yahoo.co.in
} 
such as Decalepis hamiltonii by Giridhar et al. (2004); Vaccinium corymbosum (Billings et al. 1988); Pyrus communis (Leblay et al. 1991); Elaegnus angustifolia (Economou and Maloupa, 1995); Pistachio vera L. cv. Siirt (Tilkat and Onay, 2009); Morus alba (Chitra and Padmaja, 2005); Phellodendron amurense (Azad et al. 2005). This is the first report on indirect organogenesis and the establishment of complete plantlets from the regenerated leaf and internode explants of $H$. wightii ssp. palniensis.

\section{MATERIALS AND METHODS}

\section{Establishment of In Vitro Shoot Cultures}

Single long apical bud of $0.5-1.0 \mathrm{~cm}$ was aseptically cultured in the conical flasks, each containing $50 \mathrm{ml}$ of MS medium. To establish the shoot cultures, the apical shoot tips were cultured on the MS medium containing $\mathrm{KN}(1.0 \mathrm{mg} / \mathrm{l})+$ IBA $(0.3 \mathrm{mg} / \mathrm{l})$, in addition to $30 \mathrm{~g} / \mathrm{l}$ sucrose and 8 g/l agar. A detailed method for the optimized surface sterilization and culture initiation from mature $H$. wightii spp. palniensis has been reported by Lakshmi et al. (2010). Adventitious shoot buds from the initiation medium were subcultured on the fresh initiation medium every 2-3 weeks. The regenerated adventitious shoot buds from the in vitro cultures were maintained and proliferated on the initiation medium for about six months. The $\mathrm{pH}$ of the medium was adjusted to 5.7 using $0.1 \mathrm{~N} \mathrm{NaOH}$ or $0.1 \mathrm{~N} \mathrm{HCl}$, prior to autoclaving at $121^{\circ} \mathrm{C}$ for $20 \mathrm{~min}$. All the cultures were placed and maintained in a growth room under a 16-h photoperiod $\left(60 \mu \mathrm{mol} \mathrm{m} \mathrm{s}^{-2}\right)$ with day and night temperatures of $25 \pm 2^{\circ} \mathrm{C}$.

\section{Callus Induction from Axenic Leaf and Internode Explants}

To initiate the callus induction and shoot regeneration from the axenic leaf and internode tissues, in vitro-regenerated shoots maintained for nearly six months on the culture initiation medium were used as source material. Semi mature leaf and internode were excised and abaxial sides in contact with the medium. The MS callus induction medium supplemented with $3 \%(\mathrm{w} / \mathrm{v})$ sucrose at different concentrations of auxins $2,4-\mathrm{D}$ or NAA or IBA or Pic at $0.5,1.0,1.5,2.0,3.0$ and $4.0 \mathrm{mg} / \mathrm{l}$ were tested in the callus induction experiment. These cultures were incubated at $25 \pm 2^{\circ} \mathrm{C}$ in dark for seven days and then they were transferred to 16/8h light incubation. The cultures were observed constantly for any morphological response and after four weeks in culture, the percentage of explants showing callus induction was recorded. Each treatment contained at least 20 explants and the experiment was repeated two times.

\section{Shoot Regeneration from Callus}

The primary callus of green compact nature was then transferred to the culture bottles containing shoot regeneration medium. The MS medium supplemented with $3 \%$ sucrose and different concentrations and combinations of $\mathrm{BA}, \mathrm{KN}$ or TDZ at $0.5,1.0,1.5$ and $2.0 \mathrm{mg} / \mathrm{l}$ and auxins such as IAA, IBA and NAA at the concentrations of $0.1,0.2,0.5$ and $1.0 \mathrm{mg} / \mathrm{l}$ were tested in the shoot regeneration experiments. The cultures were observed constantly for the percentage of explants regenerating shoots via adventitious shoot buds induction and proliferation.

\section{Shoot Multiplication and Elongation}

The adventitious shoots regenerated from the adventitious buds were used for further multiplication. $\mathrm{GA}_{3}(0.5 \mathrm{mg} / \mathrm{l})$ was added to the shoot regeneration medium for shoot elongation. The shoot regeneration medium used was MS medium supplemented with BA $(1.0 \mathrm{mg} / \mathrm{l})+\mathrm{IBA}$ $(0.5 \mathrm{mg} / \mathrm{l})$. After elongation, the clusters of apical shoots $(5-10 \mathrm{~mm}$ long) were segmented and used for proliferation and multiplication studies. Four different concentrations each of AA $(25,50,100$ and $150 \mathrm{mg} / \mathrm{l}), \mathrm{CA}(5,10,25$ and $50 \mathrm{mg} / \mathrm{l}), \mathrm{PVP}$ $(10,25,50$ and $100 \mathrm{mg} / \mathrm{l}), \mathrm{CE}(25,50,100$ and $150 \mathrm{mg} / \mathrm{l})$, YE $(25,50,100$ and $150 \mathrm{mg} / \mathrm{l}), \mathrm{ME}$ $(25,50,100$ and $150 \mathrm{mg} / \mathrm{l})$ and $\mathrm{CW}(5,10,15$ and $25 \%)$ were added separately to shoot regeneration medium, i.e., $\mathrm{MS}+\mathrm{BA}(1.0 \mathrm{mg} / \mathrm{l})+\mathrm{IBA}(0.5 \mathrm{mg} / \mathrm{l})$ and $\mathrm{GA}_{3}(0.5 \mathrm{mg} / \mathrm{l})$ were added based on the response observed in previous two experiments, and they were added in this assessment along with the additives to enhance its shoot multiplication rate. For shoot proliferation and multiplication, each treatment was replicated twice and each replicate consisted of at least 20 explants. Four weeks after the culturing, the percentage of number of shoots and shoot length of newly formed shoots were recorded.

\section{In Vitro Rooting of Shoots}

Elongated shoots ( $>3 \mathrm{~cm}$ long) harvested from the six times subculture were used for the rooting. The shoots longer than $3 \mathrm{~cm}$ were transferred to a 
rooting medium containing the MS medium with $3 \%$ sucrose and $8 \mathrm{~g} / \mathrm{l}$ agar. The effects of the different concentrations of IBA, IAA and NAA $(0.1,0.2$ and $0.3 \mathrm{mg} / \mathrm{l})$ on rooting were evaluated. For rooting studies, each treatment was replicated three times, and each experiment consisted of at least 10 explants. After four weeks, the percentage of rooted shoots and the number of roots per shoot were recorded.

\section{Acclimatization}

The rooted shoots were carefully taken out of the medium and washed thoroughly in the running tap water, being careful not to damage the roots, to remove the traces of the medium attached to the roots. Then, they were planted in 3-cm paper cups containing a sterile $1: 1: 1(\mathrm{w} / \mathrm{w} / \mathrm{w})$ red soil to sand and coconut coir mixture, enriched with a $1 / 4$ strength MS salt solution, covered with a polythene bag to maintain the high humidity, and placed in a culture room at $25 \pm 2^{\circ} \mathrm{C}$ (day and night). The polythene bags were opened for 5 mins each the first two days, the length of the opening time doubled each subsequent day. Then, following four week period of acclimatization by the progressive reduction of the humidity level from 90 to $60 \%$, the established plants were transferred to earthen pots and kept in a shade house for further growth and observation at Vattakanal Conservatory Trust, Kodaikanal as a part of reintroduction.

\section{Experimental Design and Data Collection}

All the experiments were conducted using the completely randomized block design. Significance was determined by the analysis of variance, and the least significant $(\mathrm{P} \leq 0.05)$ differences among the mean values were estimated using Duncan's new Multiple Range Test.

\section{RESULTS AND DISCUSSION}

A number of preliminary experiments revealed that the phytohormones were essential for the induction of callus from the leaf and internode explants and no callus was induced by the basal MS medium only. A series of attempts were made to initiate the shoots from the primary callus using the individual cytokinins. It was noticed that the $\mathrm{KN}$, BA and TDZ failed to initiate the shoot buds from the callus and the callus explant died within a short period. In order to obtain the alternate source of explant for indirect shoot regeneration, axenic cultures derived by the protocol of Lakshmi et al. (2010) was used as explant. This is the first report on organogenesis of $\mathrm{H}$. wightii ssp. palniensis. In general, the explants derived from the micropropagated shoots have an early and greater capacity for morphogenesis than the tissue excised from the field plants (George 1996), which is attributed to the absence of lag period between the explanting and adaptation to in vitro conditions. The presence of smaller yet active meristematic centers of the microplants compared to relatively larger but quiescent meristems of the shoots of mature plants might be the reason for the successful regeneration of the explants from the micropropagated shoots in the present study (Amin and Jaiswal 1987).

The leaf and internode explants from the axenic shoots served as the explants for the induction of organogenic callus. The callus initiation was observed on the cut edges of leaf and internodes 15 days after the culture incubation (including initial seven days dark incubation). The induction of callus was mainly influenced by the auxin type and concentration used (Table 1). Initially (15 days), all the calli were yellow to white in color (Fig.1) with soft, friable and unorganized morphology. This callus was sub-cultured every two weeks (15d) for 60 days on to fresh medium of the same composition after which the callus showed varied nature on the different types of auxins used (Table 1). Most of the calli became yellow to green compact organogenic in nature after a total of 60 days (Fig. 1 A and B). Only green compact callus was investigated further and reported in this study.

The mean percentage of callus induction of in vitro leaf ranged from $20.0-83.6 \%$ while the internode ranged from $20-100 \%$ based on the concentration of auxins used (Table 1). Maximum percentage of the organogenic callus was obtained on MS medium supplemented with NAA (1.0 $\mathrm{mg} / \mathrm{l})$ and 2,4-D $(2.0 \mathrm{mg} / \mathrm{l})$. NAA supplementation on callus induction has been reported on Saintpanlia ionantha (Khan et al. 2007).

\section{Effect of Cytokinins on Shoot Regeneration}

Sixty days old organogenic callus obtained from the callus induction medium was transferred to the shoot regeneration medium containing MS basal medium supplemented with BA, KN or TDZ. For the leaf-derived callus, a higher number of responses of shoot regeneration was obtained 
when the culture medium was supplemented with BA $1.0 \mathrm{mg} / \mathrm{l}(78 \%)$ with 8.4 shoots/explant (Table 2 and Fig. $1 \mathrm{C}$ ). For the internode-derived callus, significant difference was detected among the cytokinin media supplementation treatments, and the explant responsiveness ranged from 56.0$87.2 \%$ and maximum number of shoots/explant was obtained on MS medium fortified with BA 1.0 $\mathrm{mg} / \mathrm{l}$. BA has long been used most frequently for the in vitro shoot regeneration and multiplication studies of many plants. It showed high cytokinin activity by promoting the shoot multiplication and growth of leaf explant of Momordica cymbalaria (Nikam et al. 2009); Elaeagnus angustifolia (Karami and Piri 2009) and from internode of Withania somnifera (Kulkarni et al. 2000) and Piper colubrinum (Kelkar and Krishnamurthy 1998). This was reflected in the present study too.

Table 1 - Callus induction of Hoya wightii ssp. palniensis, from leaf and internode explant on MS medium supplemented with different concentrations of auxins, after 60 days of culture.

\begin{tabular}{|c|c|c|c|c|}
\hline \multirow{2}{*}{$\begin{array}{l}\text { PGRs } \\
\text { (mg/l) }\end{array}$} & \multicolumn{2}{|c|}{ Percentage of response } & \multicolumn{2}{|c|}{ Color and nature of the callus } \\
\hline & Leaf & Internode & Leaf & Internode \\
\hline 0 & 0 & 0 & - & - \\
\hline \multicolumn{5}{|l|}{ Pic } \\
\hline 0.5 & $75.4 \pm 0.2^{c}$ & $83.5 \pm 0.5^{b}$ & WFr & GC \\
\hline 1.0 & $83.6 \pm 0.5^{\mathrm{a}}$ & $100.0 \pm 0^{\mathrm{a}}$ & WFr & GC \\
\hline 1.5 & $83.5 \pm 0.1^{\mathrm{a}}$ & $100.0 \pm 0^{\mathrm{a}}$ & WFr & GC \\
\hline 2.0 & $80 \pm 0.3^{\mathrm{b}}$ & $25.0 \pm 0.4^{\mathrm{i}}$ & WFr & GC \\
\hline 3.0 & $25 \pm 0.7^{g}$ & - & WFr & GC \\
\hline \multicolumn{5}{|l|}{$2,4-\mathrm{D}$} \\
\hline 0.5 & $33.3 \pm 0.6 \mathrm{f}$ & $33.3 \pm 0.2^{\mathrm{h}}$ & $\mathrm{YC}$ & Wfr \\
\hline 1.0 & $50.0 \pm 0.8^{\mathrm{d}}$ & $57.1 \pm 0.6^{\mathrm{f}}$ & YC & GC \\
\hline 1.5 & $50.0 \pm 0.2^{\mathrm{d}}$ & $75.0 \pm 0.5^{\mathrm{d}}$ & YC & Wfr \\
\hline 2.0 & $40.0 \pm 0.4^{\mathrm{e}}$ & $50.0 \pm 0.8^{\mathrm{g}}$ & YC & GC \\
\hline 3.0 & $20.0 \pm 0.2^{\mathrm{h}}$ & $50.0 \pm 0.1^{\mathrm{g}}$ & YC & GC \\
\hline \multicolumn{5}{|l|}{ NAA } \\
\hline 0.5 & $75.0 \pm 0.1^{\mathrm{c}}$ & $50.0 \pm 0.4^{\mathrm{g}}$ & GC & Brfr \\
\hline 1.0 & $80.0 \pm 0.7^{\mathrm{b}}$ & $100.0 \pm 0^{\mathrm{a}}$ & GC & GC \\
\hline 1.5 & $40.0 \pm 0.6^{\mathrm{e}}$ & $80.0 \pm 0.1^{\mathrm{c}}$ & GC & YC \\
\hline 2.0 & $33.0 \pm 0.3^{\mathrm{f}}$ & $60.0 \pm 0.5^{\mathrm{a}}$ & GC & Wfr \\
\hline 3.0 & $20.0 \pm 0.5^{\mathrm{h}}$ & $50.0 \pm 0.3^{g}$ & GC & Wfr \\
\hline \multicolumn{5}{|l|}{ IBA } \\
\hline 0.5 & $40.0 \pm 0.3^{\mathrm{e}}$ & $80.0 \pm 0.6^{\mathrm{c}}$ & Brfr & Brfr \\
\hline 1.0 & $40.0 \pm 0.8^{\mathrm{e}}$ & $60.0 \pm 0.2^{\mathrm{e}}$ & Brfr & $\mathrm{Brfr}$ \\
\hline 1.5 & $20.0 \pm 0.4^{\mathrm{h}}$ & $20.0 \pm 0.3^{\mathrm{j}}$ & Brfr & $\mathrm{Brfr}$ \\
\hline 2.0 & - & - & - & - \\
\hline 3.0 & - & - & - & - \\
\hline
\end{tabular}

Multiple Range Test.

Table 2 - Shoot regeneration from callus of Hoya wightii ssp. palniensis on MS medium supplemented with different concentrations of cytokinins, after 60 days of culture.

\begin{tabular}{|c|c|c|c|c|c|c|c|c|}
\hline \multicolumn{3}{|c|}{ Plant growth regulators $(\mathrm{mg} / \mathrm{l})$} & \multicolumn{2}{|c|}{$\begin{array}{c}\text { Percentage of explants forming } \\
\text { shoots }\end{array}$} & \multicolumn{2}{|c|}{ No. of shoots/explants } & \multicolumn{2}{|c|}{ Shoot length (cm) } \\
\hline BA & $\mathbf{K N}$ & TDZ & Leaf & Internode & Leaf & Internode & Leaf & Internode \\
\hline 0.0 & 0.0 & 0.0 & - & - & - & - & - & - \\
\hline 0.5 & & & $75 \pm 0.3^{\mathrm{b}}$ & $78 \pm 0.2^{b}$ & $2.9 \pm 0.5^{\mathrm{h}}$ & $4.0 \pm 0.2^{\mathrm{g}}$ & $1.2 \pm 0.4^{\mathrm{h}}$ & $1.8 \pm 0.2^{\mathrm{g}}$ \\
\hline 1.0 & & & $78 \pm 0.5^{\mathrm{a}}$ & $82 \pm 0.6^{\mathrm{a}}$ & $8.4 \pm 0.3^{\mathrm{a}}$ & $11.2 \pm 0.4^{\mathrm{b}}$ & $3.4 \pm 0.5^{\mathrm{a}}$ & $4.0 \pm 0.4^{\mathrm{a}}$ \\
\hline 1.0 & & & $70 \pm 0.7^{\mathrm{d}}$ & $75 \pm 0.4^{\mathrm{c}}$ & $8.1 \pm 0.4^{\mathrm{ab}}$ & $11.8 \pm 0.9^{\mathrm{a}}$ & $2.5 \pm 0.7^{\mathrm{c}}$ & $3.4 \pm 0.5^{\mathrm{b}}$ \\
\hline \multirow[t]{9}{*}{2.0} & 0.5 & & $66 \pm 0.8^{f}$ & $70 \pm 0.3^{\mathrm{e}}$ & $7.8 \pm 0.3^{\mathrm{bc}}$ & $11.0 \pm 0.4^{\mathrm{b}}$ & $2.0 \pm 0.2^{\mathrm{e}}$ & $2.6 \pm 0.1^{\mathrm{d}}$ \\
\hline & $\begin{array}{l}0.5 \\
1.0\end{array}$ & & $68 \pm 0.3^{\mathrm{e}}$ & $72 \pm 0.6^{\mathrm{d}}$ & $3.0 \pm 0.5^{\mathrm{h}}$ & $4.2 \pm 0.3^{\mathrm{g}}$ & $2.0 \pm 0.5^{\mathrm{e}}$ & $2.3 \pm 0.4^{\mathrm{e}}$ \\
\hline & 1.0 & & $72 \pm 0.2^{\mathrm{c}}$ & $75 \pm 0.8^{c}$ & $6.3 \pm 0.7^{\mathrm{de}}$ & $10.4 \pm 0.8^{c}$ & $2.8 \pm 0.7^{b}$ & $3.2 \pm 0.2^{\mathrm{c}}$ \\
\hline & 1.5 & & $65 \pm 0.8^{\mathrm{g}}$ & $68 \pm 0.7^{\mathrm{f}}$ & $6.0 \pm 0.8^{\mathrm{e}}$ & $9.8 \pm 0.9^{\mathrm{d}}$ & $2.6 \pm 0.5^{\mathrm{bc}}$ & $2.6 \pm 0.5^{\mathrm{d}}$ \\
\hline & 2.0 & 0.5 & $57 \pm 0.7^{\mathrm{i}}$ & $60 \pm 0.2^{\mathrm{i}}$ & $5.2 \pm 0.9^{f}$ & $9.4 \pm 0.5^{\mathrm{e}}$ & $2.1 \pm 0.3^{\mathrm{d}}$ & $2.0 \pm 0.6^{\mathrm{f}}$ \\
\hline & & 1.0 & $60 \pm 0.6^{\mathrm{h}}$ & $63 \pm 0.1^{\mathrm{h}}$ & $4.0 \pm 0.2^{\mathrm{g}}$ & $6.0 \pm 0.6^{\mathrm{f}}$ & $1.4 \pm 0.7^{\mathrm{g}}$ & $1.2 \pm 0.4^{\mathrm{i}}$ \\
\hline & & 1.5 & $65 \pm 0.1^{g}$ & $70 \pm 0.6^{\mathrm{e}}$ & $7.2 \pm 0.3^{\mathrm{c}}$ & $11.5 \pm 0.2^{\mathrm{a}}$ & $1.6 \pm 0.8^{\mathrm{f}}$ & $1.7 \pm 0.6^{\mathrm{h}}$ \\
\hline & & 2.0 & $58 \pm 0.5^{\mathrm{i}}$ & $65 \pm 0.4^{\mathrm{g}}$ & $6.8 \pm 0.5^{\mathrm{d}}$ & $10.3 \pm 0.1^{\mathrm{c}}$ & $2.0 \pm 0.2^{\mathrm{e}}$ & $2.5 \pm 0.3^{\mathrm{d}}$ \\
\hline & & & $55 \pm 0.4^{\mathrm{j}}$ & $56 \pm 0.6^{j}$ & $5.6 \pm 0.8^{f}$ & $9.6 \pm 0.6^{\mathrm{de}}$ & $2.0 \pm 0.4^{\mathrm{e}}$ & $2.5 \pm 0.8^{\mathrm{d}}$ \\
\hline
\end{tabular}

Values followed by the same letter within the columns are not significantly different at the 5\% level of significance according to Duncan's Multiple Range Test. 


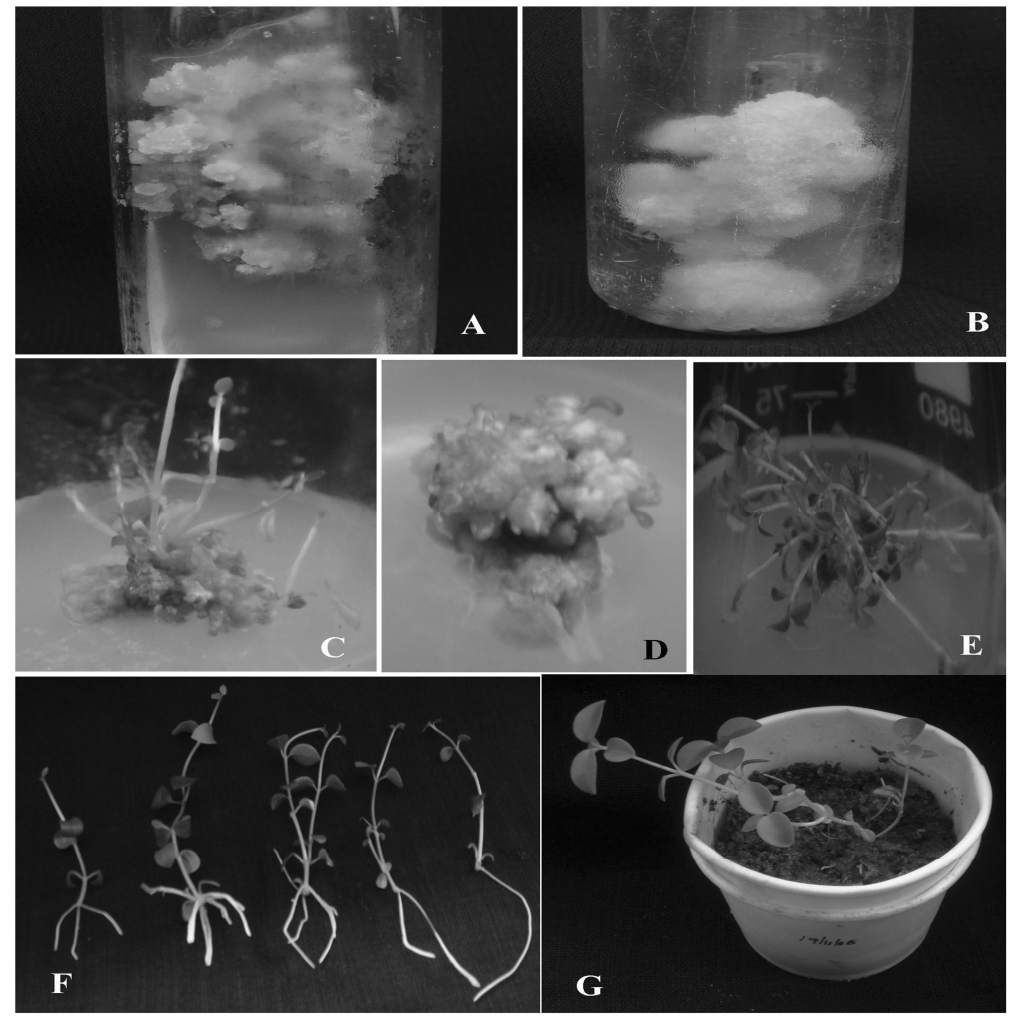

Figure 1 - Organogenesis of Hoya wightii ssp. Palniensis. A - Leaf callus; B - Internode callus; C - Shoot bud induction from leaf callus; D - Shoot bud induction from internode callus; E - Shoot multiplication; F - Rooting; G -Hardening of in vitro raised plantlets.

The better effect of BA over other cytokinins for shoot bud induction has been attributed to the abilities of plant synthetic growth regulators or to the ability of BA to induce the endogenous production of Zeatin. The MS medium supplemented with $\mathrm{KN}$ also showed marked influence on shoot formation but the number of shoots formed was lower than on BA amended medium. This could be due to the fact that the KN was less effective than the BA in the formation of multiple shoot buds (Murashige 1974). TDZ showed least percentage of response on both the explants used (Table 2). The difference in the number of shoots formed in the leaf and internode explant could be a result of difference in the regeneration potential of different explants, which was attributed by the physiological state, age and cellular differentiation among the constituent cells (Murashige 1974). Among the explants tested, the internode explant showed high morphogenic efficiency. The efficiency of the internode callus over the leaf callus might be due to the passage of some internode components from the pre-existing axillary buds that were essential to evoke the caulogenesis. Moreover, stem internodes contained sufficient cytokinins at the time of excision for the adventitious shoot production (Douglas 1984).

\section{Effect of Auxin on Shoot Multiplication}

The effect of three different auxins (IAA, IBA and NAA) was tested on shoot multiplication in the MS basal medium containing BA $(1.0 \mathrm{mg} / \mathrm{l})$. The MS basal medium amended with BA $1.0 \mathrm{mg} / \mathrm{l}$ and IBA $0.5 \mathrm{mg} / \mathrm{l}$ showed high percentage of response82.5 and $84 \%$ on leaf and internode explants, respectively. A superior response for the number of shoots 12.5 and 19.5 from the leaf and internode explants was observed on the MS medium incorporated with BA $1.0 \mathrm{mg} / \mathrm{l}+\mathrm{IBA}(0.5 \mathrm{mg} / \mathrm{l})$ (Fig. 1 E).

The superiority of the IBA over NAA and IAA on shoot regeneration through organogenesis has also been reported in other plants, including Ophiorrhiza prostrata (Beegum et al. 2007); Alibertia edulis (Silva et al. 2008); Ceropegia 
candelabrum (Beena et al. 2003) and Curcuma zedoaria (Loc et al. 2005). Next to IBA, NAA showed maximum numbers but the quality of shoots was not desirable. The NAA supplemented shoot multiplication medium resulted in basal callus formation at the concentrations used. The IAA supplementation on MS+BA $1.0 \mathrm{mg} / \mathrm{l}$ produced the least number of shoots and lower percentage for shoot multiplication. For the shoot elongation, the shoots regenerated on MS+BA 1.0 $\mathrm{mg} / \mathrm{l}+\mathrm{IBA} \quad 0.5 \mathrm{mg} / \mathrm{l}$ was transferred to $\mathrm{GA}_{3}$ supplementation at $0.5 \mathrm{mg} / \mathrm{l}$ on shoot regeneration medium (MS+BA $1.0 \mathrm{mg} / \mathrm{l}+\mathrm{IBA} 0.5 \mathrm{mg} / \mathrm{l}$ ). The $\mathrm{GA}_{3}$ supplementation not only increased the shoot length, but also increased the shoot number. $\mathrm{GA}_{3}$ stimulates the elongation by inhibiting the action of auxins in meristematic regions (Taiz and Zeiger 1998).

Table 3 - Shoot regeneration from callus of Hoya wightii ssp. palniensis on MS medium supplemented MS+BA (1.0 $\mathrm{mg} / \mathrm{l}$ ) in combination with auxins and $\mathrm{GA}_{3}$, after 60 days of culture.

\begin{tabular}{|c|c|c|c|c|c|c|c|c|c|}
\hline \multicolumn{4}{|c|}{$\begin{array}{c}\text { Plant growth regulators } \\
(\mathrm{mg} / \mathrm{l})\end{array}$} & \multicolumn{2}{|c|}{$\begin{array}{l}\text { Percentage of explants } \\
\text { forming shoots }\end{array}$} & \multicolumn{2}{|c|}{ No. of shoots/explants } & \multicolumn{2}{|c|}{ Shoot length $(\mathrm{cm})$} \\
\hline IAA & NAA & IBA & $\mathbf{G A}_{3}$ & Leaf & Internode & Leaf & Internode & Leaf & Internode \\
\hline 0.0 & 0.0 & 0.0 & & $55 \pm 0.4^{\mathrm{i}}$ & $56 \pm 0.6^{j}$ & $5.6 \pm 0.8^{j}$ & $9.6 \pm 0.6^{j}$ & $2.0 \pm 0.4^{\mathrm{j}}$ & $2.5 \pm 0.8^{j}$ \\
\hline 0.1 & & & & $65.0 \pm 0.4^{\mathrm{f}}$ & $67.4 \pm 0.3^{\mathrm{g}}$ & $8.9 \pm 0.7^{\mathrm{i}}$ & $12.3 \pm 0.3^{\mathrm{i}}$ & $3.6 \pm 0.2^{\mathrm{i}}$ & $3.4 \pm 0.2^{\mathrm{h}}$ \\
\hline 0.5 & & & & $62.3 \pm 0.4^{\mathrm{g}}$ & $64.5 \pm 0.4^{\mathrm{h}}$ & $9.2 \pm 0.8^{\mathrm{g}}$ & $13.6 \pm 0.5^{\mathrm{g}}$ & $4.7 \pm 0.4^{\mathrm{e}}$ & $3.8 \pm 0.3^{\mathrm{f}}$ \\
\hline 1.0 & & & & $60.0 \pm 0.8^{h}$ & $63.6 \pm 0.2^{\mathrm{i}}$ & $9.0 \pm 0.4^{\mathrm{h}}$ & $13.0 \pm 0.6^{\mathrm{h}}$ & $5.6 \pm 0.5^{b}$ & $2.8 \pm 0.5^{\mathrm{i}}$ \\
\hline & 0.1 & & & $70.0 \pm 0.9^{\mathrm{e}}$ & $72.5 \pm 0.4^{\mathrm{f}}$ & $9.2 \pm 0.6^{\mathrm{g}}$ & $16.2 \pm 0.7^{\mathrm{f}}$ & $4.2 \pm 0.7^{g}$ & $3.9 \pm 0.4^{\mathrm{f}}$ \\
\hline & 0.5 & & & $78.0 \pm 0.7^{\mathrm{c}}$ & $76.4 \pm 0.3^{\mathrm{d}}$ & $10.4 \pm 0.6^{\mathrm{e}}$ & $18.5 \pm 0.3^{\mathrm{c}}$ & $5.6 \pm 0.6^{\mathrm{b}}$ & $4.6 \pm 0.7^{\mathrm{d}}$ \\
\hline & 1.0 & & & $74.0 \pm 0.2^{\mathrm{d}}$ & $76.2 \pm 0.8^{\mathrm{e}}$ & $10.0 \pm 0.4^{\mathrm{f}}$ & $17.9 \pm 0.8^{\mathrm{e}}$ & $4.8 \pm 0.5^{\mathrm{d}}$ & $4.2 \pm 0.6^{\mathrm{e}}$ \\
\hline & & 0.1 & & $75.0 \pm 0.2^{\mathrm{d}}$ & $78.0 \pm 0.5^{\mathrm{d}}$ & $10.6 \pm 0.3^{\mathrm{d}}$ & $18.2 \pm 0.3^{\mathrm{d}}$ & $3.8 \pm 0.4^{\mathrm{h}}$ & $3.6 \pm 0.8^{\mathrm{g}}$ \\
\hline & & 0.5 & & $82.5 \pm 0.3^{\mathrm{b}}$ & $84.0 \pm 0.4^{\mathrm{b}}$ & $12.5 \pm 0.5^{\mathrm{b}}$ & $19.5 \pm 0.4^{\mathrm{b}}$ & $4.3 \pm 0.7^{\mathrm{f}}$ & $4.8 \pm 0.3^{\mathrm{c}}$ \\
\hline & & 1.0 & & $76.4 \pm 0.6^{\mathrm{c}}$ & $80.0 \pm 0.6^{\mathrm{c}}$ & $11.8 \pm 0.7^{\mathrm{c}}$ & $18.5 \pm 0.7^{\mathrm{c}}$ & $5.2 \pm 0.6^{c}$ & $5.6 \pm 0.4^{\mathrm{b}}$ \\
\hline & & 0.5 & 0.5 & $85.6 \pm 0.4^{\mathrm{a}}$ & $87.2 \pm 0.5^{\mathrm{a}}$ & $15.2 \pm 0.3^{\mathrm{a}}$ & $20.2 \pm 0.8^{\mathrm{a}}$ & $6.4 \pm 0.3^{\mathrm{a}}$ & $6.2 \pm 0.7^{\mathrm{a}}$ \\
\hline
\end{tabular}

Values followed by the same letter within the columns are not significantly different at the 5\% level of significance according to Duncan's Multiple Range Test.

\section{Effect of Antioxidants on Shoot Multiplication}

The effect of three different antioxidants (AA, CA and PVP) was tested on shoot multiplication in the MS medium containing BA $1.0 \mathrm{mg} / \mathrm{l}+\mathrm{IBA} 0.5$ $\mathrm{mg} / \mathrm{l}+\mathrm{GA}_{3} \quad 0.5 \mathrm{mg} / \mathrm{l}$. The shoot multiplication obtained from the regeneration medium containing the antioxidants showed maximum number of shoots than that on regeneration medium containing auxins and cytokinins, i.e., MS+BA 1.0 $\mathrm{mg} / \mathrm{l}+\mathrm{IBA} \quad 0.5 \mathrm{mg} / \mathrm{l}+\mathrm{GA}_{3} \quad 0.5 \mathrm{mg} / \mathrm{l}$. MS medium incorporated with BA $1.0 \mathrm{mg} / \mathrm{l}+\mathrm{IBA} \quad 0.5$ $\mathrm{mg} / \mathrm{l}+\mathrm{GA}_{3} \quad 0.5 \mathrm{mg} / \mathrm{l}+\mathrm{AA} 150 \mathrm{mg} / \mathrm{l}$ was higher to that containing the CA or PVP on shoot multiplication (Table 4). The optimum concentration of the AA, CA and PVP on shoot multiplication was 150,50 and $25 \mathrm{mg} / \mathrm{l}$, respectively. The maximum number of shoots/explant (31.4) was obtained at $150 \mathrm{mg} / \mathrm{l} \mathrm{AA}$ supplementation.

AA has also been shown to possess a stimulatory effect during the organogenesis by increasing the shoot multiplication rate of Salvia broussanetii (Mederos-Molina 2006), Lathyrus cicera (SahinDemirbag et al. 2008) and Sterculia urens
(Hussain et al. 2008). From this study, it was found that the addition of ascorbic acid in the regeneration medium was beneficial for shoot multiplication. CA supplementation showed moderate and PVP supplemented medium showed least response for shoot multiplication (Table 4).

\section{Effect of Organic Supplements on Shoot Multiplication}

The role of organic supplements on shoot multiplication was examined after optimizing the synergistic effect of auxin and cytokinin. The influence of different organic supplements $(\mathrm{CH}$, YE, ME and CW) was tested in MS basal medium containing $1.0 \mathrm{mg} / \mathrm{l} \mathrm{BA}+0.5 \mathrm{mg} / \mathrm{lBA}$ and $\mathrm{GA}_{3}$ $0.5 \mathrm{mg} / \mathrm{l}$ for shoot multiplication. The addition of $\mathrm{ME}$ and $\mathrm{CW}$ increased the number of shoots, whereas $\mathrm{CH}$ and YE showed least influence over shoot multiplication (Table 4). Shoots regenerated on MS+BA $1.0 \mathrm{mg} / \mathrm{l}+$ IBA $0.5 \mathrm{mg} / \mathrm{l}+\mathrm{GA}_{3} 0.5$ $\mathrm{mg} / \mathrm{l}+\mathrm{CW}$ or $\mathrm{ME}$ produced more number of shoots than shoot regeneration obtained on MS+BA $1.0 \mathrm{mg} / \mathrm{l}+$ IBA $0.5 \mathrm{mg} / \mathrm{l}+\mathrm{GA}_{3} 0.5 \mathrm{mg} / \mathrm{l}+$ $\mathrm{CH}$ or YE. MS medium supplemented with $\mathrm{BA}$ 
$1.0 \mathrm{mg} / \mathrm{l}+\mathrm{IBA} 0.5 \mathrm{mg} / \mathrm{l}+\mathrm{GA}_{3} 0.5 \mathrm{mg} / \mathrm{l}+\mathrm{CW} 15 \%$ was superior to that containing malt extract or yeast extract or casein hydrolysate on shoot regeneration and multiplication (Table 4). The higher efficiency of CW over other supplements on organogenesis has also been proved in other plants, including Ananas comosus by Atique Akbar et al. (2003), Curcuma zedoaria by Loc et al. (2005) and Sterculia urens (Hussain et al. 2008). This study showed that CW supplementation could improve the shoot multiplication in $H$. wightii ssp. palniensis as it was composed of many amino acids, nitrogenous compounds, inorganic supplements, organic acids, sugars and their alcohols, vitamins, growth substances (Cytokinins and auxins) and many other unknown components (George 1993). This could make $\mathrm{CW}$ a unique natural supplement in plant tissue culture studies. The optimum concentration of $\mathrm{CW}, \mathrm{ME}, \mathrm{CH}$ and $\mathrm{YE}$ on shoot multiplication was $15 \%, 25 \mathrm{mg} / \mathrm{l}, 25 \mathrm{mg} / \mathrm{l}$ and 50 $\mathrm{mg} / \mathrm{l}$ respectively. The maximum number of shoots/explant (31.6) was produced at $15 \% \mathrm{CW}$ supplementation. Malt extract supplementation produced moderate response, whereas $\mathrm{YE}$ and $\mathrm{CH}$ amended medium showed least response for shoot multiplication (Table 4).

Table 4 - Shoot regeneration from callus of Hoya wightii ssp. palniensis on MS medium supplemented MS+BA (1.0 $\mathrm{mg} / \mathrm{l})+\mathrm{IBA}(0.5 \mathrm{mg} / \mathrm{l})+\mathrm{GA}_{3}(0.5 \mathrm{mg} / \mathrm{l})$ with additives after 3 weeks.

\begin{tabular}{|c|c|c|c|c|c|c|}
\hline \multirow{2}{*}{$\begin{array}{l}\text { Additives } \\
\text { (mg/l) }\end{array}$} & \multicolumn{2}{|c|}{ Percentage of response } & \multicolumn{2}{|c|}{ No. of Shoots /explant } & \multicolumn{2}{|c|}{ Shoot length $(\mathrm{cm})$} \\
\hline & Leaf Callus & Internode Callus & Leaf callus & Internode callus & Leaf callus & Internode callus \\
\hline 0 & $12.3 \pm 0.5^{\mathrm{p}}$ & $11.6 \pm 0.2 \mathrm{a}$ & $15.2 \pm 0.3^{\mathrm{m}}$ & $20.2 \pm 0.8^{1}$ & $6.4 \pm 0.3^{\mathrm{q}}$ & $6.2 \pm 0.7^{\mathrm{o}}$ \\
\hline \multicolumn{7}{|l|}{ AA } \\
\hline 25 & $31.5 \pm 0.2^{\mathrm{gh}}$ & $49.5 \pm 0.2^{\mathrm{e}}$ & $24.8 \pm 0.3^{\mathrm{c}}$ & $25.4 \pm 0.5^{\mathrm{e}}$ & $9.66 \pm 0.3^{1}$ & $8.66 \pm 0.2^{\mathrm{n}}$ \\
\hline 50 & $34.2 \pm 0.4^{\mathrm{g}}$ & $70 \pm 0.3^{\mathrm{g}}$ & $22.6 \pm 0.2^{\mathrm{fg}}$ & $24.0 \pm 0.3^{\mathrm{f}}$ & $9.18 \pm 0.4^{\mathrm{p}}$ & $9.12 \pm 0.5^{\mathrm{m}}$ \\
\hline 100 & $39.3 \pm 0.3^{\mathrm{fg}}$ & $59 \pm 0.7^{\mathrm{ef}}$ & $31.4 \pm 0.7^{\mathrm{a}}$ & $30.6 \pm 0.5^{\mathrm{c}}$ & $9.82 \pm 0.7^{\mathrm{k}}$ & $9.6 \pm 0.7^{\mathrm{j}}$ \\
\hline 150 & $42.0 \pm 0.5^{\mathrm{fg}}$ & $72.3 \pm 0.6^{\mathrm{g}}$ & $29.8 \pm 0.5^{\mathrm{b}}$ & $30.2 \pm 0.4^{\mathrm{d}}$ & $10.3 \pm 0.6^{\mathrm{i}}$ & $9.2 \pm 0.3^{\mathrm{lm}}$ \\
\hline \multicolumn{7}{|l|}{$\mathrm{CA}$} \\
\hline 5 & $20.2 \pm 0.2^{\mathrm{kl}}$ & $23.8 \pm 0.3^{\mathrm{ef}}$ & $22.4 \pm 0.3^{\text {gh }}$ & $21.0 \pm 0.3^{\circ}$ & $9.26 \pm 0.2^{\circ}$ & $9.0 \pm 0.5^{\mathrm{k} 1}$ \\
\hline 10 & $21.1 \pm 0.9^{\mathrm{ijk}}$ & $23.4 \pm 0.4^{\mathrm{gf}}$ & $21.6 \pm 0.2^{\mathrm{jk}}$ & $23.0 \pm 0.5^{\mathrm{i}}$ & $9.54 \pm 0.5^{\mathrm{m}}$ & $9.5 \pm 0.7^{\mathrm{h}}$ \\
\hline 25 & $22.3 \pm 0.1^{\mathrm{ij}}$ & $24.1 \pm 0.4^{\mathrm{def}}$ & $22.6 \pm 0.6^{\mathrm{fg}}$ & $22.6 \pm 0.3^{\mathrm{i}}$ & $10.3 \pm 0.6^{\mathrm{j}}$ & $10.1 \pm 0.9^{\mathrm{h}}$ \\
\hline 50 & $22.6 \pm 0.3^{i j}$ & $24.1 \pm 0.3^{\mathrm{def}}$ & $23.4 \pm 0.4^{\mathrm{e}}$ & $23.4 \pm 0.2^{\mathrm{h}}$ & $12.1 \pm 0.6^{\mathrm{b}}$ & $12.7 \pm 0.3^{\mathrm{a}}$ \\
\hline \multicolumn{7}{|l|}{ YE } \\
\hline 25 & $47.2 \pm 0.4^{\mathrm{d}}$ & $49.1 \pm 0.6^{\mathrm{d}}$ & $21.4 \pm 0.7^{\mathrm{jkl}}$ & $21.6 \pm 0.2^{\mathrm{m}}$ & $10.3 \pm 0.1^{\mathrm{i}}$ & $9.6 \pm 0.2^{\mathrm{j}}$ \\
\hline 50 & $50.5 \pm 0.5^{\mathrm{c}}$ & $52.2 \pm 1.5^{\mathrm{e}}$ & $22.6 \pm 0.8^{\mathrm{fg}}$ & $22.0 \pm 0.7^{1}$ & $12.2 \pm 0.6^{\mathrm{a}}$ & $12.1 \pm 0.5^{\mathrm{b}}$ \\
\hline 100 & $34.2 \pm 0.3^{g}$ & $36.7 \pm 1.3^{\mathrm{c}}$ & $22.2 \pm 0.1^{\mathrm{hi}}$ & $21.0 \pm 0.4^{\mathrm{o}}$ & $10.2 \pm 0.4^{\mathrm{j}}$ & $10.0 \pm 0.6^{\mathrm{h}}$ \\
\hline 150 & $30.3 \pm 0.4^{\mathrm{gh}}$ & $31.6 \pm 0.9^{c}$ & $21.6 \pm 0.4^{\mathrm{jk}}$ & $22.0 \pm 0.6^{1}$ & $11.8 \pm 0.4^{\mathrm{c}}$ & $12.1 \pm 0.3^{b}$ \\
\hline \multicolumn{7}{|l|}{$\mathrm{CH}$} \\
\hline 25 & $19.5 \pm 0.2^{\mathrm{klm}}$ & $19 \pm 0.8^{\mathrm{a}}$ & $22.6 \pm 0.5^{\mathrm{fg}}$ & $22.6 \pm 0.6^{j}$ & $10.8 \pm 0.5^{\mathrm{f}}$ & $11.3 \pm 0.5^{\mathrm{c}}$ \\
\hline 50 & $16.2 \pm 0.4^{\mathrm{n}}$ & $17 \pm 0.5^{\mathrm{a}}$ & $22.4 \pm 0.4^{\mathrm{gh}}$ & $22.4 \pm 0.7^{j}$ & $11.4 \pm 0.6^{\mathrm{d}}$ & $11.3 \pm 0.7^{\mathrm{c}}$ \\
\hline 100 & $14.6 \pm 0.3^{\text {no }}$ & $15 \pm 0.4^{\mathrm{a}}$ & $23.2 \pm 0.8^{\mathrm{e}}$ & $22.4 \pm 0.3^{j}$ & $9.68 \pm 0.2^{1}$ & $10.1 \pm 0.5^{\mathrm{h}}$ \\
\hline 150 & $15.3 \pm 0.7^{\mathrm{no}}$ & $17 \pm 0.6^{\mathrm{a}}$ & $23.2 \pm 0.9^{\mathrm{e}}$ & $23.0 \pm 0.5^{\mathrm{i}}$ & $10.4 \pm 0.7^{\mathrm{h}}$ & $10.0 \pm 0.3^{\mathrm{h}}$ \\
\hline \multicolumn{7}{|l|}{ ME } \\
\hline 25 & $21.4 \pm 0.8^{\mathrm{ij}}$ & $23 \pm 0.7^{\mathrm{b}}$ & $22.2 \pm 0.5^{\mathrm{hi}}$ & $21.6 \pm 0.6^{\mathrm{m}}$ & $11.1 \pm 0.6^{\mathrm{e}}$ & $11.08 \pm 0.6^{\mathrm{d}}$ \\
\hline 50 & $26.3 \pm 0.6^{\mathrm{hi}}$ & $28 \pm 0.9^{b c}$ & $22.0 \pm 0.6^{\mathrm{f}}$ & $22.2 \pm 0.3^{\mathrm{k}}$ & $11.4 \pm 0.6^{\mathrm{d}}$ & $10.8 \pm 0.4^{\mathrm{c}}$ \\
\hline 75 & $25.2 \pm 0.4^{\mathrm{hi}}$ & $27 \pm 0.2^{\mathrm{bc}}$ & $22.0 \pm 0.7^{\mathrm{i}}$ & $21.6 \pm 0.2^{\mathrm{m}}$ & $11.4 \pm 0.9^{\mathrm{d}}$ & $9.9 \pm 0.7^{\mathrm{i}}$ \\
\hline 100 & $23.0 \pm 0.3^{\mathrm{ij}}$ & $25 \pm 0.4^{b c}$ & $21.2 \pm 0.4^{\mathrm{jkl}}$ & $23.8 \pm 0.1^{\mathrm{g}}$ & $10.2 \pm 1.0^{\mathrm{j}}$ & $9.9 \pm 0.8^{\mathrm{i}}$ \\
\hline \multicolumn{7}{|l|}{$\mathrm{CW}(\%)$} \\
\hline 5 & $42.6 \pm 0.3^{f}$ & $34 \pm 1.2^{c}$ & $22.4 \pm 0.4^{\mathrm{gh}}$ & $23.0 \pm 0.5^{\mathrm{i}}$ & $9.3 \pm 0.4^{\mathrm{n}}$ & $9.2 \pm 0.7^{1}$ \\
\hline 10 & $62.1 \pm 0.5^{\mathrm{ab}}$ & $36 \pm 1.5^{\mathrm{c}}$ & $31.4 \pm 0.3^{\mathrm{a}}$ & $30.8 \pm 0.6^{\mathrm{b}}$ & $10.4 \pm 0.5^{\mathrm{h}}$ & $9.9 \pm 0.9^{\mathrm{i}}$ \\
\hline 15 & $53.0 \pm 1.2^{\mathrm{c}}$ & $39 \pm 1.3^{\mathrm{cd}}$ & $31.6 \pm 0.5^{\mathrm{a}}$ & $31.2 \pm 0.1^{\mathrm{a}}$ & $9.3 \pm 0.7^{\mathrm{n}}$ & $9.5 \pm 0.4^{\mathrm{k}}$ \\
\hline 25 & $63.7 \pm 0.7^{\mathrm{a}}$ & $45 \pm 0.7^{\mathrm{d}}$ & $23.8 \pm 0.3^{\mathrm{d}}$ & $22.2 \pm 0.5^{\mathrm{k}}$ & $9.4 \pm 0.1^{\mathrm{n}}$ & $9.6 \pm 0.5^{\mathrm{j}}$ \\
\hline \multicolumn{7}{|l|}{ PVP } \\
\hline 10 & $20.5 \pm 0.6^{\mathrm{kl}}$ & $23.2 \pm 0.6^{\mathrm{fg}}$ & $21.6 \pm 0.5^{\mathrm{j}}$ & $21.6 \pm 0.2^{\mathrm{m}}$ & $10.2 \pm 0.2^{\mathrm{j}}$ & $10.3 \pm 0.5^{\mathrm{f}}$ \\
\hline 25 & $19.7 \pm 0.7^{\mathrm{klm}}$ & $22.3 \pm 0.8^{\mathrm{g}}$ & $21.0 \pm 0.6^{1}$ & $21.6 \pm 0.3^{\mathrm{m}}$ & $10.3 \pm 0.4^{\mathrm{i}}$ & $10.2 \pm 0.7^{\mathrm{g}}$ \\
\hline 50 & $19.5 \pm 0.3^{\mathrm{klm}}$ & $22.3 \pm 0.3^{\mathrm{g}}$ & $21.6 \pm 0.3^{\mathrm{jk}}$ & $20.8 \pm 0.7^{\circ}$ & $10.7 \pm 0.7^{\mathrm{g}}$ & $10.4 \pm 0.5^{\mathrm{f}}$ \\
\hline 100 & $19.0 \pm 0.2^{\mathrm{klm}}$ & $22.3 \pm 0.2^{\mathrm{g}}$ & $21.2 \pm 0.7^{\mathrm{jkl}}$ & $21.2 \pm 0.2^{\mathrm{n}}$ & $9.5 \pm 0.2^{\mathrm{m}}$ & $9.9 \pm 0.3^{\mathrm{i}}$ \\
\hline
\end{tabular}

Values followed by the same letter within the columns are not significantly different at the 5\% level of significance according to Duncan's Multiple Range Test. 


\section{Rooting}

The shoots after multiplication were isolated and transferred on to the MS medium containing different auxins. The mean percentage of rooting ranged from 50-76, $0-50$ and $0-80 \%$ were recorded on the rooting medium, supplemented with NAA, IAA and IBA, respectively. The highest rooting response $(80 \%)$ (Table 5) was obtained on the MS medium supplemented with
IBA, with an average root length of $4.6 \mathrm{~cm}$. These observations were consistent with those reported by Salma et al. (2008), Raha and Roy (2003), Neeta Mishra et al. (2003) and Atique Akbar et al. (2003). The efficacy of the NAA at lower concentrations in vitro rooting has been reported in various medicinal plants, e.g., Verbascum thapsus L. (Turker et al. 2001) and Santolina canescens Lagasca (Casado et al. 2002).

Table 5 - In vitro rooting of Hoya wightii ssp. palniensis on MS medium supplemented with different concentrations of auxins, after 30 days of culture period.

\begin{tabular}{|c|c|c|c|c|}
\hline $\begin{array}{l}\text { Plant Growth } \\
\text { Regulator(mg/l) }\end{array}$ & $\begin{array}{c}\text { Days to initiate } \\
\text { root }\end{array}$ & $\begin{array}{c}\text { Average No. of } \\
\text { roots/microshoot }\end{array}$ & Root length (cm) & $\begin{array}{c}\text { Rooting } \\
\text { percentage }\end{array}$ \\
\hline 0.0 & - & - & - & - \\
\hline \multicolumn{5}{|l|}{ NAA } \\
\hline 0.01 & $10-12$ & $4.2 \pm 0.6^{\mathrm{b}}$ & $4.2 \pm 0.6^{\mathrm{cd}}$ & $75 \pm 0.6^{\text {cd }}$ \\
\hline 0.05 & $10-12$ & $3.5 \pm 0.1^{\mathrm{c}}$ & $4.5 \pm 0.2^{\mathrm{bc}}$ & $76 \pm 0.2^{\mathrm{bc}}$ \\
\hline 0.1 & $10-12$ & $3.1 \pm 0.2^{\mathrm{d}}$ & $3.7 \pm 0.1^{\mathrm{ef}}$ & $50 \pm 0.5^{\mathrm{e}}$ \\
\hline 0.2 & $9-12$ & $2.7 \pm 0.2^{\mathrm{e}}$ & $3.3 \pm 0.3^{\mathrm{g}}$ & $50 \pm 0.3^{\mathrm{e}}$ \\
\hline 0.3 & $9-12$ & $2.7 \pm 0.1^{\mathrm{e}}$ & $2.5 \pm 0.6^{\mathrm{h}}$ & $50 \pm 0.1^{\mathrm{e}}$ \\
\hline \multicolumn{5}{|l|}{ IBA } \\
\hline 0.01 & - & - & - & - \\
\hline 0.05 & $7-10$ & $1.3 \pm 0.1^{\mathrm{hi}}$ & $0.8 \pm 0.1^{\mathrm{j}}$ & $50 \pm 0.3^{\mathrm{e}}$ \\
\hline 0.1 & $7-10$ & $1.4 \pm 0.1^{\mathrm{gh}}$ & $4.5 \pm 0.1^{\mathrm{bc}}$ & $75 \pm 0.1^{\text {cd }}$ \\
\hline 0.2 & $7-10$ & $5.3 \pm 0.1^{\mathrm{a}}$ & $4.6 \pm 0.1^{b}$ & $80 \pm 0.2^{\mathrm{a}}$ \\
\hline 0.3 & $7-10$ & $3.1 \pm 0.2^{\mathrm{d}}$ & $4.5 \pm 0.3^{\mathrm{bc}}$ & $78 \pm 0.3^{\text {ab }}$ \\
\hline \multicolumn{5}{|l|}{ IAA } \\
\hline 0.01 & - & - & - & - \\
\hline 0.05 & $7-9$ & $16 \pm 0.6^{\mathrm{fg}}$ & $3.8 \pm 0.6^{\mathrm{e}}$ & $25 \pm 0.1^{\mathrm{f}}$ \\
\hline 0.1 & $7-9$ & $1.7 \pm 0.1^{\mathrm{f}}$ & $6.4 \pm 0.2^{\mathrm{a}}$ & $50 \pm 0.2^{\mathrm{e}}$ \\
\hline 0.2 & $5-8$ & $1.3 \pm 0.1^{\mathrm{hi}}$ & $1.4 \pm 0.1^{\mathrm{i}}$ & $50 \pm 0.4^{\mathrm{e}}$ \\
\hline 0.3 & $5-8$ & - & - & - \\
\hline
\end{tabular}

Values followed by the same letter within the columns are not significantly different at the 5\% level of significance according to Duncan's Multiple Range Test.

\section{Acclimatization of Regenerated Plants}

The rooted plants with three-four fully expanded leaves and well-developed roots were transferred to the pots containing red soil, sand and coconut coir $(1: 1: 1)$. Normal growth for the potted plants was observed after four weeks of transfer. After two months, they were transferred to larger pots containing the same ingredients and moved to a green house. After transplantation to soil, $70 \%$ of the rooted plantlets survived and grew to maturity when transferred to a green house (Fig. $1 \mathrm{G}$ ). The regenerated plants did not show visible varieties in the morphological or growth characteristics when compared to the donor plants.

\section{CONCLUSION}

This is the first report describing a protocol for organogenesis of $H$. wightii ssp. palniensis. The presence of the cytokinin BA in combination with IBA and $\mathrm{GA}_{3}$ was required for the efficient shoot multiplication and proliferation. The addition of $\mathrm{AA}$ and $\mathrm{CW}$ was useful for the improvement of shoot regeneration. The IBA favored the root induction and development. The explants derived from the micropropagated shoots showed better organogenic potential than the explants from the mature plants.

The organogenesis and plant regeneration system developed in this study could be utilized in future for the in vitro culture, transformation and secondary metabolites production experiments. 


\section{ACKNOWLEDGEMENTS}

We acknowledge financial support from the University Grants Commission, New Delhi and Mr. R.W. Stewart and Mrs. Tanya Balcar and their team of Vattakkanal Conservation Trust, Kodaikanal for the help rendered during the reintroduction program.

\section{REFERENCES}

Amin MN, Jaiswal VS. Clonal propagation of guava through in vitro shoot proliferation on nodal experiments of mature trees. Plant Cell Tiss Org Cult. $1987 ; 9 ; 235-244$.

Atique Akbar M, Karmakar BK, Roy SK. Callus induction and high-frequency plant regeneration of Pineapple (Ananas comosus (L.) Merr.). Plant Tiss Cult. 2003; 13(2): 109-116.

Azad MAK, Yokota S, Ohkubo T, Andoh Y, Yahara S, Yoshizawa N. In vitro regeneration of the medicinal woody plant Phellodendron amurense Rupr. through excised leaves. Plant Cell Tiss Org Cult. 2005; 80: 43-50.

Beegum AS, Martin KP, Zhang CL, Nishitha IK, Ligimol Slater, Madhusoodanan A. Organogenesis from leaf and internode explants of Ophiorrhiza prostrata, an anticancer drug (camptothecin) producing plant. Electronic J Biotech. 2007; 10(1): 114-123.

Beena MR, Martin KP, Kirti PB, Molly Hariharan. Rapid in vitro propagation of medicinally important Ceropegia candelabrum. Plant Cell Tiss Org Cult. 2003; 72: 285-289.

Billings SG, Chin CK,Jelenkovic G. Regeneration of blue-berry plantlets from leaf segments. Hort Sci. 1988; 23: 763-766.

Casado JP, Navarro MC, Utrilla MP, Martinez A, Jimenez J. Micropropagation of Santolina canescens Lagasca and in vitro volatile production by shoot explants. Plant Cell Tiss Org Cult.2002; 69: 147-153.

Chitra DS, Padmaja G. Shoot regeneration via direct organogenesis from in vitro derived leaves of mulberry using thidiazuron and 6-benzylaminopurine. Sci Hort. 2005; 106: 593-602.

Douglas GC. Formation of adventitious buds in stem internodes of Populus species cultured on in vitro on basal medium: influence of endogenous properties of explants. J Plant Physiol.1984; 116: 313-321.

Economou AS, Maloupa EM. Regeneration of Elaeagnus angustifolia from leaf segments of in vitro-derived shoots. Plant Cell Tiss Org Cult. 1995; 40: 285-288.

George EF. Plant Propagation by Tissue Culture. Part II. Exegetics Ltd., Erdington, UK.1996.
Giridhar P, Vinod Kumar, Ravishankar GA. Somatic embryogenesis, organogenesis and regeneration from leaf callus culture of Decalepis hamiltonii Wight \& Arn., an endangered shrub. In vitro Cell Dev Biol Plant. 2004; 40: 567-571.

Hussain TM, Chandrasekhar T, Gopal GR. Micropropagation of Sterculia urens Roxb., an endangered tree species from intact seedlings. Afr $J$ Biotechnol. 2008; 7(2): 95-101.

Karami O, Piri K. Shoot organogenesis in Oleaster (Elaeagnus angustifolia L.). Afr J Biotechnol. 2009; 8(3): 438-440.

Kelkar SM, Krishnamurthy KV. Adventitious shoot regeneration from root, internode, petiole and leaf explants of Piper colubrinum Link. Plant Cell Rep. 1998; 17: 721-725.

Khan S, Naseeb S, Ali K, Callus induction, plant regeneration and acclimatization of African violet (Saintpaulia ionantha) using leaves as explants. Pak J Bot. 2007; 39(4):1263-1268.

Kulkarni AA, Thengane SR, Krishnamurthi, KV. Direct shoot regeneration from node, internode, hypocotyl and embryo explants of Withania somnifera. Plant Cell Tiss Org $\quad$ Cult. 2000;2 : 203-209.

Lakshmi SR, Franklin Benjamin JH, Senthil Kumar T, Murthy GVS, Rao MV. In vitro propagation of Hoya wightii ssp. palniensis K.T.Mathew, a highly vulnerable and endemic species of Western Ghats of Tamil Nadu. Afr J Biotech. 2010; 9(5): 620-627.

Leblay C, Chevreau E, Raboin LM. Adventitious shoot regeneration from in vitro leaves of several pear cultivars (Pyrus communis L.). Plant Cell Tiss Org Cult. 1991;25: 99-105.

Loc NH, Duc DT, Kwon TH, Yang MS. Micropropagation of zedoary (Curcuma zedoaria Roscoe) - a valuable medicinal plant. Plant Cell Tiss Org Cult. 2005; 81: 119-122.

Maraffa SB, Sharp WR, Tayama HK, Fretz TA. Apparent asexual embryogenesis in cultured leaf sections of Hoya carnosa. Z Pflanzen Physiol. 1981; 102: 45-56.

Mathew KT. The Hoyan. 1992; 14 (1): 3, t.1.

Matthew KM. Matthew. III. Fl. Palni Hills, 1996; t. 511.

Mederos-Molina S. Micropropagation of Salvia broussonetii Benth. - A medicinal Plant Species. Plant Tissue Cult Biotech. 2006; 16 (1): 19-23.

MurashigeT. Plant propagation through tissue culture. Annu Rev Plant Physiol. 1974; 25: 136-166.

Murashige T, Skoog F. A revised medium for rapid growth and bioassays for tobacco tissue cultures. Physiol Plant. 1962; 15: 473-497.

Neeta Mishra, Pratibha Mishra, Datta SK, Shanta MJ. Improvement in clonal propagation of Hemidesmus indicus $\mathrm{R}$. Br. through adenine sulphate. J Plant Biotech. 2003; 5(4): 239-244. 
Nikam TD, Ghane SG, Nehul JN, Barmukh RB. Induction of morphogenic callus and multiple shoot regeneration in Momordica cymbalaria Fenzl. Indian J Biotechnol. 2009; 8: 442-447.

Raha S, Roy SC. Efficient plant regeneration in Holarrhena antidysentrica Wall, from shoot segmentderived callus. In Vitro Cell Dev Biol- Plant. 2003; 39: 151-155.

Sahin-Demirbag N, Kendir H, Khawar KM, Ciftci CY. In vitro regeneration of Tirkish dwarf chickling (Lathyrus cicera L.) using immature zygotic embryo explant. Afr J Biotechnol. 2008; 7(12): 2030-2033.

Salma U, Rahman MSM, Islam S, Haque N, Jubair TA, Haque AKMF, Mukti IJ. The influence of different hormone concentration and combination on callus induction and regeneration of Rauwolfia serpentina L. Benth. Pak J Biol Sci. 2008; 11(12): 1638-1641.

Silva FAB, Pereira LAR, Silveira CES. Micropropagation of Alibertia edulis Rich. Braz Arch Biol Technol. 2008; 51(6): 1103-1114.
Taiz L, Zeiger E. Plant Physiology. Massachusetts: Sinauer Associates, 1998; 792.

Tilkat E, Onay A. Direct shoot organogenesis from in vitro-derived mature leaf explants of pistachio. In vitro Cell Dev Biol Plant. 2009; 45: 92-98.

Tube Y, Xiao T, Leung K, Leung K-P, Yan G, Xiao S$\mathrm{Y}$, et al. Leaf ball tissue culture and rapid propagation test Hoya kerrii in vitro and its rapid propagation. Tropical Agric Sci Technol. 2007; 30(2) (Abstract only).

Turker AU,Camper ND, Gurel E. In vitro culture of common mullein (Verbascum thapsus L.). In Vitro Cell Dev Biol Plant. 2001; 37: 40-43.

Received: January 27, 2011; Revised: July 02, 2011; Accepted: Setember 29, 2012. 